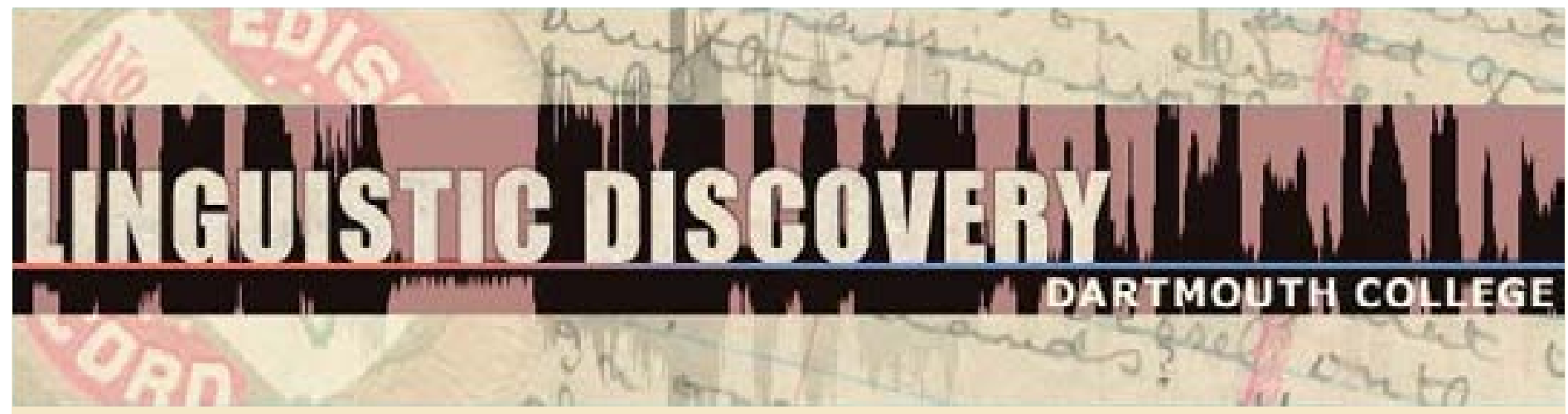

\begin{tabular}{|l|}
\hline Volume 2 \\
Issue 2 \\
2004 \\
\hline
\end{tabular}

\title{
A Crosslinguistic Lexicon of the Labial Flap
}

Kenneth S. Olson and John Hajek

SIL International \& University of North Dakota, University of Melbourne

doi: 10.1349/PS1.1537-0852.A.262

url: http://journals.dartmouth.edu/cgi-bin/WebObjects/ Journals.woa/1/xmlpage/1/article/262

Linguistic Discovery

Published by the Dartmouth College Library Copyright to this article is held by the authors. ISSN 1537-0852 linguistic-discovery.dartmouth.edu 


\title{
A Crosslinguistic Lexicon of the Labial Flap ${ }^{1}$
}

\author{
Kenneth S. Olson and John Hajek \\ SIL International \& University of North Dakota, University of Melbourne
}

We provide a large sample of the occurrences of the labial flap in the world's languages, including audio and video data from the Mono dialect of Mid-Southern Banda. This sample provides the evidence for Olson and Hajek's (2003) crosslinguistic generalizations concerning the articulation, the geographic distribution, the genetic distribution, and the phonological status of the speech sound.

\section{Introduction}

The labial flap has until recently been poorly documented and consequently poorly understood. Olson and Hajek (2003) provide a crosslinguistic study of the speech sound, discussing its geographic and genetic distributions, and drawing generalizations concerning its articulation and phonological status. The present paper provides most of the data on which Olson and Hajek's conclusions are drawn. These data represent a large sample of the occurrences of the labial flap in the world's languages. They come from an extensive survey of the literature as well as previously unpublished data from both our own field work and that of other researchers.

It is, in our view, important to document as fully as possible the existence of the labial flap in the world's languages for the following reasons:

(1) This demonstrates that the labial flap is not such an unusual sound, a point confirmed by the large number of languages we find it in, which are located across a number of language families and on two different continents.

(2) Previous typological research on African phonology has tended to focus on tone and other prosodic phenomena. The investigation of segmental phenomena has tended to be hampered by a lack of easy access to data. The collation of data for Olson and Hajek (2003) and for this paper has taken considerable time over a number of years, and it seems beneficial to make these data available in one place in order to assist other linguists.

Here is a summary of our findings in Olson and Hajek (2003). First, we find the following generalizations regarding the articulation of the sound. In terms of phonetic articulatory parameters, the labial flap is most commonly produced as a voiced labiodental flap with egressive pulmonic air. A bilabial variant is attested in 13 languages, and in some cases, such as in the Mono dialect of Mid-Southern Banda, this variant is preferred. A secondary articulation of velarization has been observed in Mangbetu and Mono. Following the International Phonetic

\footnotetext{
${ }^{1}$ We wish to thank everyone who shared data with us (see personal communications within the text). This paper could not have been written without their contributions. Thanks to Bruce Connell for technical assistance in making the audio and video recordings of the Mono data; to Ama Geangozo Mbanza and Kilio Tembenekuzu for providing the Mono language data; and to Mark Karan for helpful comments on the text.
} 
Association's (IPA 1989: 70) convention, we transcribe the labiodental and bilabial variants as $<\breve{\mathrm{V}}>$ and $<\breve{\mathrm{W}}>$, respectively. We transcribe the data in this paper using the IPA.

Second, concerning the geographic distribution of the labial flap, it is almost exclusively attested in Africa. We find 67 (possibly 69) languages containing the sound in north central Africa and four (possibly five) languages in southeastern Africa. The present understanding of the expansion of the Bantu-speaking peoples allows for the possibility that the sound spread via contact from north central Africa to the languages presently in southeastern Africa, so we cannot assume that it arose independently in each of these regions. The Austronesian language Sika spoken in Indonesia contains a sound whose articulatory description is identical to that found in Africa, but more research is necessary to verify that this is indeed the same sound. Of all the features that have been proposed in the literature as possibly being uniquely African areal features, the labial flap comes closest to actually being one (see, e.g., Greenberg 1983; Heine 2003).

Third, concerning the genetic distribution of the labial flap, it is found in three of the four major language families in Africa, but only in restricted sets of sub-branches in each family. In Niger-Congo, it is found in 23 (possibly 25) Ubangian languages, twelve Adamawa languages, and eight (possibly nine) Benue-Congo languages. In Nilo-Saharan, it is found in 14 Central Sudanic languages. In Afro-Asiatic, it is found in 14 Chadic languages. As mentioned before, it is possibly attested in one Austronesian language.

Thus, the sound is most widely attested in Adamawa-Ubangi. If the sound had a single source, it was most likely in this sub-group, with subsequent spread via contact into languages of other families in close geographic proximity (see Olson and Hajek 2003 for a further discussion). Whether the sound emerged as a sound-symbolic element or from a regular sound change remains an outstanding question.

Fourth, concerning the phonological status of the labial flap, it clearly can pattern as a phonological unit in language. Olson and Hajek (2003) show that it has been incorporated into the general phonological system of the following number of languages:

$\begin{array}{lccc} & \text { Definite } & \text { Probable } & \text { Possible } \\ \text { Ubangi } & 9 & 4 & 4 \\ \text { Adamawa } & 3 & 1 & 2 \\ \text { Central Sudanic } & 1 & 2 & 2 \\ \text { Chadic } & 0 & 1 & 0 \\ \text { Austronesian } & 0 & 1 & 0 \\ \text { Total: } & \mathbf{1 3} & \mathbf{9} & \mathbf{8}\end{array}$

Phonological status is evaluated based on the following diagnostics: contrast (minimal or near-minimal pairs), distribution across grammatical categories (taking into account the special status of ideophones, taboo words, and plant and animal names), frequency of occurrence, distribution within the word, core vocabulary, borrowed words, co-occurrence with following vowels, and researchers' judgments. Because the sound is an active phonological element in such a large number of languages, theories of phonological features or phonetic parameters must take it into account.

Figure 1 maps the African languages in which the labial flap is reported. Chadic languages are marked in grey, Benue-Congo in dark yellow, Adamawa in green, Ubangi in teal, West Central Sudanic in red, and East Central Sudanic in violet. Languages in which the labial flap is 
definitely incorporated into the phonological system are surrounded by a double-box, probably by a single box, and possibly by an oval. Parentheses around a code indicate that evidence for the existence of the labial flap in that language is questionable.

In this paper, we present each language in which we have evidence that the sound is found. This comprehensive language listing not only documents the data upon which our observations are made, it is also intended to serve as a useful time-saving resource for future research on the labial flap-bringing together as it does much published and unpublished data, often extremely difficult to locate.

For each language, we provide the following information: the language name as listed in the Ethnologue (Grimes 2000; each language listed is considered a mutually unintelligible speech variety therein), its Ethnologue code, the language code employed in Figure 1, the name used by a researcher if it differs from the Ethnologue name (indicated in parentheses as alt. "name"), the country or countries in which the language is spoken, the reference that includes the first known mention of the labial flap in the literature for the language, and additional sources which provide significant data. We discuss briefly the articulation of the sound, particularly noting if it is bilabial or labiodental. If the precise place of articulation is not described, we simply refer to it as "labial". We provide evidence concerning the phonological status of the sound in the language, following the diagnostics mentioned above. Finally, we provide all the words and glosses that we have collected for the language. In the case of Mono, we also provide audio and video recordings. 


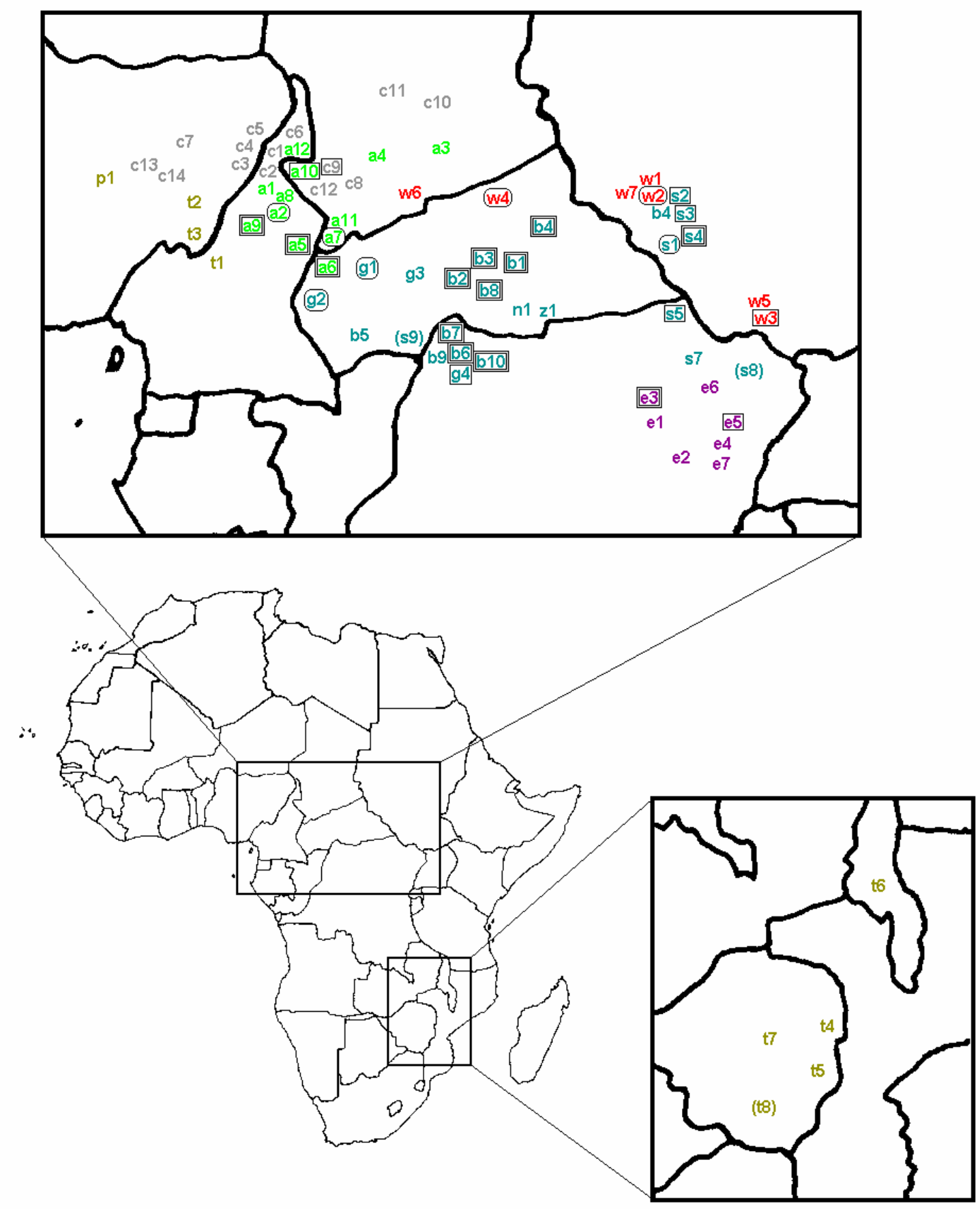

Figure 1: Geographic distribution of the labial flap in Africa.

In Figure 1, data concerning the location of languages is from Grimes (2000) and Moseley and Asher (1994). 


\section{Chadic}

The labial flap is attested in fourteen Chadic languages. No evidence for contrast is given by any of the sources. The sound is found almost exclusively in ideophones, with most additional items being animal names. Several sources report the sound as being rare, and this appears to be the case in most of the languages cited, but an in-depth study of the sound in Kera unearthed over 60 words. It is usually found in intervocalic position in these languages.

\subsection{Bana [BCW, c1] (Cameroon)}

Hofmann (1990) refers to the sound as "labiodental”, but she notes that the lower lip may strike the upper teeth, the upper lip, or both. It occurs only in intervocalic position. She considers it a marginal phoneme. She attests it in the following items:

Nouns

gàvèy 'fishhook'

Ideophones

báv̌áp báv̆ák 'of setting off running'

gàvèp 'of falling in the mud'

gáv̆̀̀m 'of letting something fall in the water'

wáv̆àm 'of swallowing suddenly'

wàv̆áp 'on interfering in the affairs of others'

2.2 Daba [DAB, c2] (Cameroon, Nigeria). labiodental

Lienhard and Giger (1975), Tadadjeu and Sadembouo (1979:24), and Hartell (1993:62-3, 70). Tadadjeu and Sadembouo refer to it as a "vibrante labiodentale 1 bat.”

$\breve{v i} \breve{v} \dot{i n} \quad$ 'fish' (Tadadjeu and Sadembouo)

kiv̄àt 'to strip’ (Lienhard and Giger)

2.3 Gude [GDE, c3] (Nigeria, Cameroon)

Mo Perrin (p.c.) cites one rare ideophone: $\breve{v} u 6$ 'hit!'.

\subsection{Kamwe [HIG, c4] (Nigeria)}

Mohrlang (1972:23, 35, 42) reports a labiodental "flapped fricative" in the Nkafa dialect of Kamwe. He includes the sound in his phoneme chart, but he does not provide evidence of contrast. He considers it rare. He attests it in two ideophones:

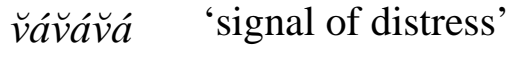

biv̌ifé '(ideophone)' 


\subsection{Marghi Central [MAR, c5] (Nigeria)}

Hoffmann (1963) and Ladefoged (1968:18; 1971:52; 1982:154-5). The first two sources explicitly mention a flap against the upper teeth. Ladefoged (1968:18) indicates that the flap is preceded by a stop component in which "the lower lip is tensed against the upper lip and teeth." Hoffmann attests the flap in the following ideophones:

bá $\breve{v} u \quad$ 'of sudden appearance and flight'

háváwì 'of escape of an animal'

káv̌àh̀̀ 'of intruding into a place'

2.6 Mofu-Gudur [MIF, c6] (Cameroon). labiodental

Barreteau (1988) considers the sound to be rare. He attests it in the following ideophones: ${ }^{2}$

$\begin{array}{ll}\text { páv̆ár } & \text { 'crack' } \\ \text { pa vá́j } & \text { 'of moving on water' } \\ \breve{v a ́ p} \sim \breve{v e ́ p} & \text { 'tumble' } \\ \breve{v a ́ s l} & \text { 'fall abruptly' }\end{array}$

2.7 Tera [TER] (Nigeria, c7). labiodental

Paul Newman (p.c.) attests the sound in the word həŭəp 'the sound of a hyena falling down from a palm tree'. He notes that it is found only in onomatopoeic words.

2.8 Gabri [GAB] (Chad, c8)

James Roberts and Kaïndi Etienne (p.c.). The sound is found only in ideophones and exclamations.

\begin{tabular}{|c|c|}
\hline$\breve{v} a$ & 'expressing the force of a blow' \\
\hline$h \ddot{t} \breve{v} a d \grave{t}$ & 'indication of a wound from a sharp weapon' \\
\hline$\breve{v} \partial$ & ‘very (hard)’ \\
\hline$k i \breve{v i j}$ & ‘very (long)’ \\
\hline$i \breve{v} \ddot{i} b$ & 'indication of surprise’ \\
\hline$\breve{v i} w$ & 'yes (response to a call)’ \\
\hline
\end{tabular}

2.9 Kera [KER, c9] (Chad, Cameroon). labiodental

Mary Pearce (p.c.) attests the sound in over 60 lexical items. She does not provide evidence of contrast, but given the large number of lexical items, it is likely that contrastive pairs can be

\footnotetext{
${ }^{2}$ Barreteau says that these are adjectives or adverbs, but semantically they are clearly ideophonic.
} 
found. However, since most of the lexical items are ideophones, we cannot say definitively that the labial flap has been fully incorporated into the phonological system of Kera.

Nouns

pəॅ̆ə⿹

‘poor quality soil’ (also an ideophone)

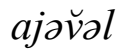

'oily sauce'

Verbs

$\breve{v}$ əkti

'make hard (e.g. make the work hard, make your head hard, meaning 'take your time'), 3

Ideophones

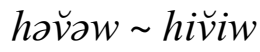

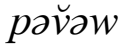

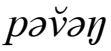

gav̆aw

$\breve{v} \partial m \sim \breve{v i m}$

hiv̌ib

$\breve{v i w}$

$\breve{v} a w$

$p \partial \breve{v} a b$

$\breve{v i w}-\breve{v} i w$

$h a \breve{v} a b i$

v̌intim

bə̌̆aw

biv̌iw

v̌intiw

$\breve{v a p i}$

be ้̌ew

$\breve{v} \partial ? i$

pav̌aw

$\breve{v e p} \sim \breve{v} a p$

biv̌iw

'(a) large; (b) too much water; (c) describing the action of piercing something with a spear'

'long'

'hot' (also a noun)

'(a) gulping down food; (b) way of jumping into water; (c) lots of water'

'(a) blood red; (b) lots of water in a well'

'(a) fall like a sack; (b) making lots of work for someone'

'the noise of something thrown'

'(a) the noise of something thrown (same as $\breve{v i w) ; ~(b) ~ t o ~ l i f t ~ s o m e t h i n g ~}$ easily'

'move in or out of something containing water'

'noise of rope or a whip turning in the air'

'exhaustion through tiredness, famine or sickness'

'a great explosion (e.g. water)'

'pass easily through something such as water'

'lining up people or animals'

'exploding noise, e.g. gun, swarm of insects'

'(a) a full container; (b) submerged in water'

'(a) lining up little people; (b) stomach noises’

'step or jump out of line'

'long, the continuation of a time away'

'small thing'

'noise of a flame, an argument that gets noisy, someone moving hurriedly to do something requiring force'

həŭati 'leave entirely'

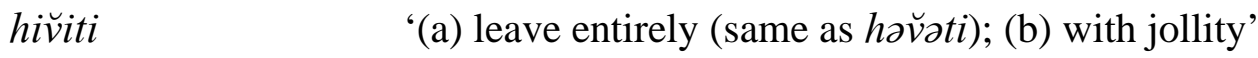

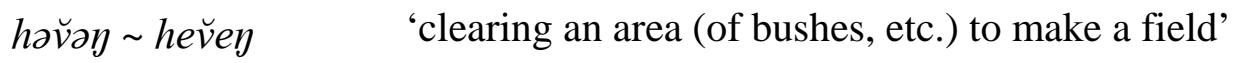

\footnotetext{
${ }^{3}$ This word is inflected in the same way that verbs are, indicating that it is a verb.
} 


\begin{tabular}{|c|c|}
\hline hǐ̌in & $\begin{array}{l}\text { '(a) clearing an area (same as } h ə \breve{v} \partial \eta \text { ); (b) the way the skin peels after } \\
\text { being whipped' }\end{array}$ \\
\hline$h \partial \breve{v} a d i$ & ‘(a) big (e.g. eye), (b) removing something big’ \\
\hline hiv̌idi & 'unburying something (an object or a problem)' \\
\hline$g \partial \breve{v} \partial l \sim g \partial \breve{v} a l$ & 'falling on an arm, leg, or neck in a way that breaks it' \\
\hline giv̌il & $\begin{array}{l}\text { '(a) fighting against something (fish in net, animal in trap); (b) death of } \\
\text { an important person' }\end{array}$ \\
\hline$\breve{v} \partial d \partial m$ & 'big (hole) or deep (water)’ \\
\hline v̆idihi & 'noise when you break a gourd' \\
\hline$\breve{v i k i}$ & '(a) hitting the head with a stick or whip; (b) pulse beat' \\
\hline 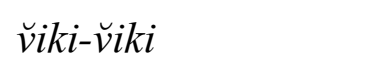 & ‘writing rapidly’ \\
\hline$\breve{v} a \eta-\breve{v} a \eta$ & $\begin{array}{l}\text { '(a) hard; (b) describing an object that comes out of the fire without } \\
\text { being destroyed (e.g. a pot)' }\end{array}$ \\
\hline$\breve{v} e \eta-\breve{v} e \eta$ & '(a) not timid; (b) red (as in ripe fruit, etc.)' \\
\hline$\breve{v} \tilde{\partial} \tilde{\partial} t i-\breve{v} \tilde{\partial} \tilde{\partial} t i$ & '(a) making a noise like a rooster instead of speaking in normal voice’ \\
\hline$\breve{v} \tilde{\partial} \tilde{\partial} t i$ & 'push your head out of a hole or out of water' \\
\hline$\breve{v} \tilde{e} \tilde{e} t i$ & 'way of disappearing or taking your time’ \\
\hline$\breve{v}$ adahi & 'breaking in two after a fall (e.g. calabash)' \\
\hline 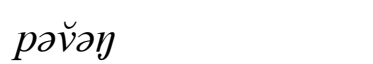 & 'soil that gives no produce' \\
\hline hav̌ati & 'peel or slide off easily (e.g. injured skin, water)' \\
\hline giv̌iw & '(a) sound of thunder; (b) a way of jumping in water’ \\
\hline giv̌i?i & 'deformity of bone structure in large people' \\
\hline 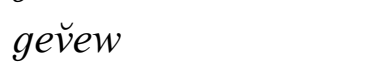 & ‘small stomach noises’ \\
\hline$k i \breve{v i w}$ & 'long (masculine object)’ \\
\hline 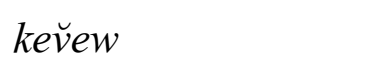 & 'way of making white, clean, or clear' \\
\hline$k a \breve{v} a w$ & $\begin{array}{l}\text { '(a) completely remove or leave (a person or object); (b) clean (e.g. } \\
\text { wash a bowl clean)' }\end{array}$ \\
\hline$k \partial \breve{v} \partial w$ & ‘long (for a well)’ \\
\hline 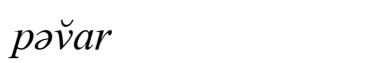 & 'a child's way of falling' \\
\hline kiv̌ì & 'the sound of metal' \\
\hline 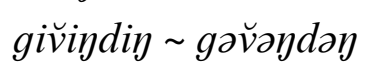 & 'big (e.g. big stick)’ \\
\hline be $\breve{v e w}$ & 'a tree that gives lots of fruit' \\
\hline 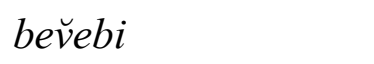 & 'fall from weakness (for a child)' \\
\hline biv̌ibi & '(a) a big person falling; (b) big/large (e.g. work, argument)’ \\
\hline$\breve{v} a k i$ & $\begin{array}{l}\text { '(a) a confirmation; said when someone sneezes while someone else is } \\
\text { saying something true; (b) fall freely and with force to the ground; (c) } \\
\text { height of a goat' }\end{array}$ \\
\hline 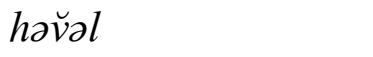 & ‘sound of many things falling on an object or person’ \\
\hline$\breve{v} \partial p i$ & '(a) submerged in water; (b) sound of arrow when it hits' \\
\hline$\breve{v i l}$ & 'big (e.g. a ball)’ \\
\hline
\end{tabular}


bavaw 'noise of a projectile passing through the leaves of trees'

bəŭ $\quad$ 'to catch fire, to lift oneself up'

həv̆ว?i 'rope like'

2.10 Migaama [MMY, c10] (Chad). labiodental

Jungraithmayr and Adams (1992), Semur (1997, cited by Bill Chesley, p.c.). The sound occurs only in ideophones and in word-medial position.

kavac 'whipping noise-a cooking term’ (Jungraithmayr and Adams 1992:17)

purup 'noise of the beating of wings' (Semur 1997:I)

2.11 Mukulu [MOZ, c11] (Chad). labiodental

Jungraithmayr (1990:196) (Mokilko dialect). He describes it as a "coup fricatif dentilabial”. This is most likely a labiodental flap, but the description is unclear.

wúvù̀m 'noise of falling in water'

2.12 Pevé [LME, c12] (Chad, Cameroon)

Venberg (1975) includes it in his phoneme inventory, but he does not provide clear evidence of contrast. It does not occur in intervocalic position.

$\breve{v a o} \quad$ 'once upon a time'

vì 'slingshot'

\subsection{Ron [CLA, c13] (Nigeria)}

Phil Davison (p.c.) reports a labiodental flap during the playing of the game awali (popularly known as Mancala in the U.S.). At the point where the last stone is put in a hole so that a player succeeds in getting the opponent's stones, the player exclaims $\breve{v i}$.

\subsection{Yiwom [GEK, c14] (Nigeria)}

Jungraithmayr (1965:172) (alt. “Gerka”), Greenberg (1983:12) (alt. “Gerka”). Jungraithmayr uses the symbol $<\mathrm{f}>$ to refer to the sound, which may indicate a voiceless articulation. However, Greenberg uses $\mathrm{a}<\mathrm{v}>$ with left loop to represent the sound in the same lexical item. Both Jungraithmayr and Greenberg attest it in the word kav̌in 'buffalo'. 


\section{Benue-Congo}

\subsection{Bantoid}

The labial flap is found in three Northern Bantoid languages (Kwanja, Samba Daka, and Tep) in Cameroon and Nigeria and four Narrow Bantu languages in southeastern Africa. No evidence for contrast is given by any of the sources. It is found almost exclusively in ideophones. Except for Shona, most sources give only one or two examples. None of the sources consider the sound to be phonemic.

\subsubsection{Kwanja [KNP, t1] (Cameroon). labiodental}

Weber and Weber (1987), Blench (1993). Weber and Weber state that it is pronounced with some nasalization. They note that it only occurs in ideophones and is very rare. They give the following example:

kíté v̌íwù 'Rabbit took off out of sight!'

\subsubsection{Samba Daka [CCG, t2] (Nigeria)}

Boyd (1994:47, 64, 154, 162), Cloarec-Heiss (1998). Boyd attests it in the following words:

$\begin{array}{ll}\breve{v} \bar{a} a ̀ t & \text { 'hit' } \\ \breve{v} e ́ k & \text { 'split' }\end{array}$

\subsubsection{Tep [MZK, t3] (Nigeria)}

Bruce Connell (p.c.). Grimes (1996) considers Tep to be a dialect of Mambila, but Connell considers Tep to be a separate language. He attests it in the lexical item śv̌́g 'spiggot used specifically to tap palm wine'.

3.1.4 Manyika [MXC, t4; Guthrie zone S] (Zimbabwe, Mozambique)

Hannan (1974:728) cites one ideophone: $\breve{v}$ ojo 'of disappearing into thick grass or forest'.

3.1.5 Ndau [NDC, t5; Guthrie zone S] (Zimbabwe)

Doke (1931:224) describes the sound as either "infra-labial” (i.e. bilabial) or "denti-labial” (i.e. labiodental). He attests it in the ideophone $k$ 'ut' $i \breve{v u}$ 'thud'.

3.1.6 Nyanja [NYJ, t6; Guthrie zone N] (Malawi, Botswana, Mozambique, Tanzania, Zambia, Zimbabwe). labiodental

Scott (1929:590, 598) attests the sound in the words $\breve{v} a$ 'beating, hitting' and wo $\breve{v} o$ 'disappearing into', which both appear to be ideophones. 
3.1.7 Shona [SHD, t7; Guthrie zone S] (Zimbabwe, Botswana, Malawi, Zambia)

Doke (1931:224) (Karanga, Zezuru, and Korekore dialects). The sound has the same articulation as in Ndau. It is attested only in ideophones. In one ideophone in the Zezuru dialect, the sound is voiceless, but in fact, the entire word is voiceless: $\breve{y} a$ 'of report of a gun'. See also Fortune (1962:30).

$\breve{v} i \quad$ 'of hollow thud' (Korekore)

kutiv̌i 'to thud on something hollow' (Zezuru, Korekore)

$\breve{v} \breve{v} O \quad$ 'of striking on the mouth (Karanga)' or 'of flicking' (Zezuru) (Hannan 1974:714 transcribes this as $\breve{v} o$ )

hov $\breve{1}$ 'of animals rushing unseen through grass' (Karanga)

3.1.8 Kalanga [KCK, (t8); Guthrie zone S] (Zimbabwe, Botswana)

Doke (1931:224) reports a labial flap in the Rozi dialect of Kalanga (the $<\mathrm{z}>$ in "Rozi" is an "alveolar labialized voiced fricative"). The articulation is the same as in Ndau. He attests the sound in the ideophone kov̌o 'of cattle covering the veld'.

He notes (p. 14) that the Rozi people were scattered and that in many places they spoke the local language instead of Rozi (Doke did his field work in 1929). It is possible that this dialect is now extinct. Grimes (1996:460) states, "Rozvi (Rozwi, Ruzwi, Chirozwi) speak Karanga dialect and do not have their own language. They are dispersed over many areas of the country.”

\subsection{Platoid}

The labial flap is attested in one Platoid language.

\subsubsection{Nungu [RIN, p1] (Nigeria)}

In the Linguist List posting 8.45 [http://www.linguistlist.org/issues/8/8-45.html], Carten Peust states, "According to M[ary] Ward, a language in Nigeria called Rindre, Nungu, Wamba and a few other names possesses a labiodental flap.” No articulatory description or data are given.

\section{Adamawa}

The labial flap is attested in twelve Adamawa languages. It is most common in the Mbum-Day subgroup. Sources provide evidence for contrast in Karang and Mbum. In most languages, it occurs either in all grammatical categories or in more than one. It is well-attested in several languages. It is usually only found in word-initial position. Researchers consider it to be phonemic in Karang, Kare, Kuo, and Mbum. 
4.1 South Fali [FAL, a1] (Cameroon). labiodental

Ennulat and Ennulat (1971) (alt. "Fali de Ram"; this is likely the "Fali" referred to by CloarecHeiss 1998). Ennulat and Ennulat report the flap in the words vàktá 'clench the teeth' and vàmndá 'slap'.

\subsection{Dii [DUR, a2] (Cameroon)}

Boyd (1974:83) (alt. "Dourou”), Bohnhoff (1982) (alt. "Yag Dii” or “Duru”), Segerer (1995, cited by France Cloarec-Heiss, p.c.) (alt. "Duru”), Cloarec-Heiss (1998) (alt. "Duru”). Boyd (1974) considers the articulation either bilabial or labiodental. Bohnhoff (1982) considers it to be labiodental. He notes that it can occur in different grammatical categories. Boyd attests it in the word $\breve{v}$ ' 'to throw'. Bohnhoff attests it in the words pív̌íd 'very steep', buv̌ud 'fast', and bá 'sound of a horse galloping'. This last word is the only example in our data of the flap in wordfinal position.

\subsection{Gula Iro [GLJ, a3] (Chad)}

Pairault (1969) (Pongaal dialect of alt. "Kulaal”), Cloarec-Heiss (1998) (alt. "Kulaal”). Pairault considers the articulation to be bilabial. He notes that the sound is voiceless in word-initial position and voiced in intervocalic position. He attests the sound in two ideophones w̧óò and ’́w̌́p , both which mean 'bang/boom'. He does not consider the sound to be phonemic.

4.4 Niellim [NIE, a4] (Chad). labiodental

Diane Vanderkooi (p.c.) attests the sound in the ideophone kiv̌vab 'definitively'.

\subsection{Karang [KZR, a5] (Cameroon, Chad)}

Boyd (1974:82-3) (alt. "Ndó Mbàli”), Ubels and Ubels (1980), Bob Ulfers (p.c.). Boyd considers the sound either bilabial or labiodental, whereas Ubels and Ubels consider the sound to be labiodental. They note that the articulation of the sound is the same as in Shona, but different from Margi (cf. Ladefoged 1971:52).

Ubels and Ubels and Ulfers present contrast between the labial flap and other labial sounds (reproduced in Olson and Hajek 2003). The sound is well-attested in Karang, occurring in over a dozen words (see below). It occurs in all major grammatical categories in Karang, including nouns, verbs, and ideophones. It usually occurs in word-initial position, but is also attested in word-medial position in two words. Of particular interest is its occurrence following a consonant (presumably across a syllable boundary) in pekv̌ekvek 'very high'. This is the only case in our data of the sound occurring adjacent to a stop. It is attested before all vowels in Karang except $\supset$.

Nouns

vara 'animal'

$\breve{v} u j \quad$ 'kind of grass' 
Verbs

$\begin{array}{ll}\breve{v} \bar{e} & \text { 'to cut' } \\ \breve{v} \bar{l} & \text { 'to ask' } \\ \breve{v} \grave{i} r & \text { 'to brew' } \\ \breve{v} \grave{o} l & \text { 'to distinguish' } \\ \breve{v} \bar{u} & \text { 'to throw away' }\end{array}$

Ideophones

valay 'very'

$\breve{v a w} \quad$ 'loudly'

ka $\breve{v a w} \quad$ 'out of sight'

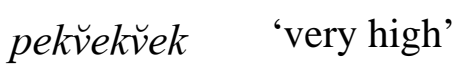

vir 'hard'

v̌irim 'whole'

$\breve{v} u b u 6 u \quad$ 'like rushing water'

4.6 Kare $[\mathrm{KBN}, \mathrm{a6}]$ (Central African Republic, Cameroon)

Boyd (1974:63, 67, 82-3) (alt. "Kali”), Lim (1997), Cloarec-Heiss (1998). Boyd considers the sound bilabial or labiodental. Lim considers it labiodental. Boyd attests the sound in the words $\breve{v} \bar{a} r$ 'man/husband', $\breve{v} o k$ 'to wash', $\breve{v} a$ 'to hit', and $\breve{v} u$ 'to throw'. Lim attests the sound in the items listed below. This includes several words that could be considered taboo.

\begin{tabular}{|c|c|}
\hline Nouns & \\
\hline$\breve{v a ̀ r a ̀ ~}$ & 'testicles' \\
\hline$g \grave{\tilde{a}} \breve{v} \overline{\tilde{a}} r \overline{\tilde{a}}$ & 'G-string' \\
\hline$\breve{v} \grave{\tilde{\varepsilon}} r \dot{\tilde{\varepsilon}}$ & 'vulva’ \\
\hline$s \grave{a} \breve{v} \grave{\varepsilon} r \grave{\varepsilon}$ & 'bitter wild yam' \\
\hline$\breve{v} \tilde{i} r \dot{\imath}$ & 'excrement' \\
\hline v̌̃írízzúrú & 'wax, polish' \\
\hline$\breve{v} \grave{\jmath} l$ & 'sorcery' \\
\hline Animal names & \\
\hline$n d \tilde{\tilde{J}} \breve{\varepsilon} \tilde{\varepsilon} r \tilde{\varepsilon}$ & 'type of insect' \\
\hline kívivírĩ & 'beetle' \\
\hline gbj̀rìv̆̀̀rò & ‘type of reptile’ \\
\hline v̌úndílí & 'type of water insect' \\
\hline
\end{tabular}

Plant names

várá 'type of tree' 


\begin{tabular}{|c|c|}
\hline gòsú ngáv̆ì & 'type of tree' \\
\hline rá & 'type of herb' \\
\hline ngàứcrá & 'type of herb' \\
\hline víì & 'type of herb' \\
\hline íviríi & 'type of tree' \\
\hline
\end{tabular}

Verbs

$\breve{v} \tilde{a}$

'hit, cry, shout'

$\breve{v e ́}$

'cut'

vèrè

'break'

vìrì

'become slack, cook many times'

$\breve{v i}$

'ask'

$\breve{v} \mathfrak{u}$

'throw'

Adjectives

$n g \grave{a} \breve{v a ̀}$

'stupid'

Ideophones

v̌y

'of a hard knock'

4.7 Kuo [KHO, a7] (Chad, Cameroon)

Boyd (1974:71) (alt. “Ko"), James Roberts (p.c.), Marcia Bleeker (p.c.). Boyd and Bleeker consider the sound to be either bilabial or labiodental. Bleeker considers the sound to be a phoneme. She notes that it occurs in nouns, verbs, adverbs, adjectives, and ideophones, and that it occurs only in word-initial position. The data below are from Bleeker except where noted.

$\begin{array}{ll}\breve{v} i & \text { 'ask' } \\ \breve{v} i ́ w & \text { 'question' } \\ \breve{v} u & \text { 'throw' } \\ \breve{v} u d u d u & \text { 'pell-mell' } \\ \breve{v} j a ́ m & \text { 'play a game' (Boyd) }\end{array}$

4.8 Mambai [MCS, a8] (Cameroon, Chad)

Eguchi (1971:141-7, 186, 192-3) reports a "labio-dentale semivoyelle” $v$ in Mambai. Stefan Elders (p.c.) confirms that it is actually a labiodental flap. It is rarer than $w$. It is found in wordinitial and word-medial positions, but in the latter it is always stem-initial. Eguchi attests the sound in the following words:

Nouns

vààlá 'testicles 


\begin{tabular}{|c|c|}
\hline$n a ́-\breve{v e ́ r g a ̀ ~}$ & 'lizard' \\
\hline v̌ízò & 'fishhook' \\
\hline v̌íliò & 'drum, tom-tom' \\
\hline v̌̀̀ná & 'male, husband' \\
\hline Verbs & \\
\hline Síl-nà & 'cut' \\
\hline ‘̌áá-nà & 'divide, share’ \\
\hline
\end{tabular}

4.9 Mbum [MDD, a9] (Cameroon, Central African Republic). labiodental

Richardson (1957) (alt. "Kapere” dialect), Hagège (1968; 1970) (West Mbum dialect, town of Nganha), Fløttum (1974, cited by Stefan Elders, p.c.), Hino (1978) (in the town of MbangMboum). Hagège refers to the sound as a stop, but later he refers to it as a vibrant (Hagège 1981).

Hagège (1970) provides contrasts with most other labial sounds (except $p, k p, g b$, and $n g b$ ). It occurs in nouns, verbs, pronouns, and ideophones. It is common, occurring in over twenty words, including the core vocabulary words $\breve{v} \hat{\imath}$ ' 'you', ${ }^{4} \breve{v} \grave{i}$ 'to ask', and $\breve{v} u$ 'to throw' The sound occurs most often in word-initial position, but it is attested in word-medial position in words which can be derived from other lexical items (e.g. ásiǔvir 'circle', bàŭı́ 'yourselves'). The following items are from Hagège (1968), Fløttum (1974) and Hino (1978).

Nouns

$\breve{v} \hat{a}$

$\breve{v a ̀ t a ̀ i ~}$

'lower jaw'

$\breve{v e}$ e $\breve{v} \hat{o n}$

'cross'

$\breve{v i \eta a ̀-m b i ̀ ~}$

'god'

v̌inà̀

'fountain'

v̌íà

'question'

v̌intínvòk

'spurting, gushing'

$\breve{v o ̀ l}$

'tibia'

'witchcraft'

Adjectives

váàaké

'large, grand'

Verbs

$\breve{v a ̀ l ~} \sim$ wàl 'to divide, distribute'

$\breve{v} \grave{a} \eta \sim h \tilde{u}$

'to become fat'

var hánà

'to separate, say goodbye'

\footnotetext{
${ }^{4}$ Richardson (1957) glosses this as second person plural.
} 
$\breve{v} e ́$

$\breve{v} \grave{e}$

$\breve{v} i$

$\breve{v i ́}$

$\breve{v} o ́$

$\breve{v} \grave{o} k$

$\breve{v o ́} \eta$

$\breve{v} u \dot{u} \sim 6 u$

$\breve{v u ́ n}$

Pronouns

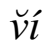

Ideophones/Adverbs

vàlàk và̀làk

vìr 'to strangle, kill by cutting one's throat'

'to amass a lot'

'to ask'

'to spring (up)'

'to overturn'

'to rinse'

'to narrow'

'to throw'

'to apply ointment'

\subsection{Mundang [MUA, a10] (Chad, Cameroon)}

Elders (2000), James Roberts (p.c.). Elders considers the sound to be labiodental. He notes that it can occur in nouns, verbs, and adverbs, but he considers all examples to be ideophonic. He attests the sound in the following words:

pávám 'disproportionately large’

báv̆àw 'black buffalo, Derby eland'

$m a ́-\breve{v} \hat{a} j \quad$ 'type of mask for initiation and mourning'

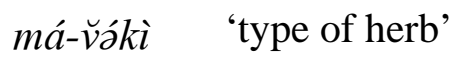

$\breve{v} \bar{y} y \quad$ 'to tan, to soften (of leather)'

\subsection{Nzakmbay [NZY, a11] (Chad, Cameroon)}

Boyd (1974) (“Nják Mbái”) and James Roberts (p.c.) (“Nzakambay”). Boyd considers the sound to be bilabial or labiodental. He attests the sound in the lexical items for $\breve{v} a$ 'to hit' and $\breve{v} u$ 'to throw'.

\subsection{Tupuri [TUI, a12] (Cameroon, Chad)}

Ruelland (1988:106) reports the sound in the ideophone giv̌̀̀w '(to swallow) fast'.

\footnotetext{
${ }^{5}$ The grave accent in this word indicates a lower mid tone.
} 


\section{Ubangi}

\subsection{Banda}

The labial flap is found in ten of the eleven Banda subgroups. The subgroup in which it is not attested is South Central Banda, which includes Langbashe (Cloarec-Heiss 1978:17). Grimes (2000) generally treats each of these subgroups as a single language, and we have followed that convention here. Sources give evidence for contrast in Banda-Bambari, Banda-Ndélé, MidSouthern Banda, and Mbandja. In most languages it is considered common, and it is attested in over twenty-five lexical items in Banda-Bambari, Banda-Banda, Banda-Mbrès, Mid-Southern Banda, Togbo-Vara Banda, West Central Banda, and Mbandja. Tisserant (1931) considers the flap a "fundamental sound" in Banda. In most languages it is attested in both word-initial and intervocalic positions.

Tisserant (1931) provides numerous examples of the labial flap. He reports no less than 33 examples of the sound which occur in the "ensemble des dialectes, ou la majeure partie d'entre eux” (p. 10). Of these examples, the flap is in word-initial position in 15 of them and in wordmedial position in 18. These examples are comprised of nouns, verbs, adverbs, and one adjective. He does not explicitly mention dialects in the Banda-Ndélé, Banda-Yangere, or Southwestern (Ngbundu) groups, so it is not clear if these 33 words are found in those subgroups. In addition to these 33 items, numerous additional items containing the flap are cited for individual dialects. We have not included his data here, due to the large amount of it.

\subsubsection{Banda-Bambari [LIY, b1] (Central African Republic). labiodental}

Tisserant (1930; 1931) (Linda, Gbwende, Djyoeto, Ngapu, and Ndokpwa dialects), CloarecHeiss (1967; 1978; 1986) (Linda dialect), Moñino (1988) (Linda dialect). Marcel Diki-Kidiri (p.c.) notes that a bilabial variant is possible.

Cloarec-Heiss (1967) provides contrasts between the labiodental flap and other labial consonants. She reports the following words:

$\begin{array}{ll}\breve{v} a & \text { 'send' } \\ \breve{v} i & \text { 'throw' } \\ \breve{v i ̀ r} ̀ & \text { 'round' } \\ \text { áv̆rá } & \text { 'force' }\end{array}$

5.1.2 Banda-Banda [BPD, b2] (Central African Republic, Sudan). labiodental Tisserant (1931) (Banda-Banda, Belingo, Ndi, Gbaga, Mbi, and Buru dialects). 5.1.3 Banda-Mbrès [BQK, b3] (Central African Republic, Sudan). labiodental Tisserant (1931) (Moruba, Wada, Mbele, and Sabanga dialects). 
5.1.4 Banda-Ndélé [BFL, b4]. (Central African Republic, Sudan). labiodental

Sampson (1985) (Tangbago dialect). Moñino (1988) (Ngao dialect). Sampson provides contrast with other labial sounds in both word-initial and intervocalic positions. He provides examples of both nouns and verbs containing the sound:

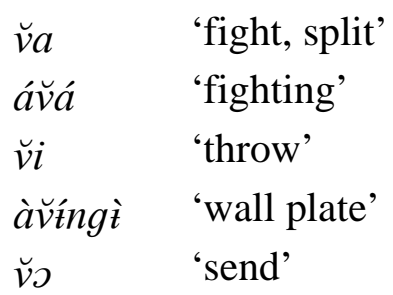

5.1.5 Banda-Yangere [YAJ, b5] (Central African Republic). labiodental

Richardson (1957), Moñino (1988). Moñino attests it in the words $\breve{v} \bar{\partial}$ 'to send' and $\breve{v} \bar{l}$ 'to throw'.

\subsubsection{Banda, Mid-Southern [BJO, b6] (Central African Republic, D.R. Congo)}

Tisserant (1931) (Bongo, Wasa, Yakpwa, Mono, and Ngobu dialects), Cloarec-Heiss (1978) (Ngundu, Gobu, Kpagua, and Yakpa dialects), Olson (1996) (Mono and Gobu dialects), Kamanda (1998), Olson and Hajek (1999), Olson and Schrag (2000), and Olson (2001) (all Mono dialect). Olson and Schrag (2000) consider the sound to be bilabial with a labiodental variant. There is a backing movement of the tongue during the articulation of the sound.

Olson and Schrag give evidence for constrast with other labial sounds (reproduced in Olson and Hajek 2003). The sound is well-attested, occurring in over 45 words. It occurs in the core vocabulary words káw̌̀ 'to throw' and káwà 'to send'. It occurs in all major grammatical categories in Mono, including nouns, verbs, and adverbs. It occurs in both word-initial and wordmedial positions. It occurs before most vowels in the language, including front, back, high, and low vowels.

The following data are from Olson (2001) except where noted. The audio samples were recorded by Brian and Barbara Schrag at the SIL recording studio in Yaoundé on March 16-18, 1998. Mike Fox was the recording engineer. The recordings were made with a Nakamichi 550 analog tape recorder and an AKG D330DT microphone. The two subjects, Speakers A and B, were both adult male native speakers of Mono, about 30 years old. A digital audio tape (DAT) copy was made in December 1999 at the University of Chicago Language Laboratories and Archives at a sampling rate of $48,000 \mathrm{~Hz}$ and then converted to WAV files using SoundDesigner II, version 2.8. The video of Speaker A was recorded by Brian Schrag and Ken Olson at SIL in Yaoundé in January 1998 and digitized at the University of Chicago Language Laboratories and Archives in December 1999. The individual frames are 30 ms apart.

Click here for a video of a labial flap (9.5 MB)

Click on links to the right for the corresponding sound clip. 
Nouns

àwútòrò

áw̌̀árá

àwéngè

ndìwá

ndéw̌tétí

àพūūrūggù

w̌àngàlúsù

$\grave{a} \breve{w} \bar{a} l \bar{a}$

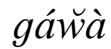

kàw̆á

káw̌wángéng $\bar{a}$

kàw̌̀̀ngòndā

àjī à $\breve{w} a ́$

būwèlè

gbàngéw̌wétà

kpíkíwùkpí

'stick used in an animal trap'

'wisdom'

Speaker A $\underline{\text { Speaker B }}$

'rainbow'

Speaker A Speaker B

'rubber'

Speaker A $\underline{\text { Speaker B }}$

'crowd'

Speaker A Speaker B

'vehicle'

Speaker A $\underline{\text { Speaker B }}$

‘syphilis’ (Kamanda 1998)

'prayer' (Kamanda 1998)

‘scoop' (Kamanda 1998)

'gruel'

‘dryness’ (Kamanda 1998)

'name of village'

'messenger'

'type of banana'

'disability'

‘filaria’ (Kamanda 1998)

Animal names

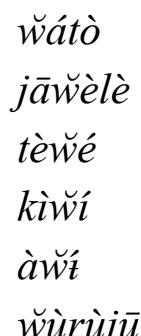

'queen ant'

Speaker A $\underline{\text { Speaker B }}$

'catfish'

Speaker A $\underline{\text { Speaker B }}$

'black ant'

Speaker A $\underline{\text { Speaker B }}$

‘type of mollusk' (Kamanda)

'hyena'

Speaker A $\underline{\text { Speaker B }}$

'dung beetle'

Speaker A $\underline{\text { Speaker B }}$

Body parts

wàlà

w̌stlé

'bone marrow'

Speaker A $\underline{\text { Speaker B }}$

'thigh'

Speaker A Speaker B

w̌ítí

'calf'

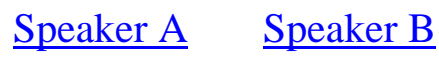

kìw̌wílì

‘hip’ (Kamanda 1998)

Verbs

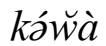

káw̆àdù

'to send'

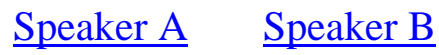

káw̆àngà

'to take out'

'to cut across'

káw̆̀̀rà

'to be fast, open'

kákàw̆à

'to snap'

Speaker A $\underline{\text { Speaker B }}$

kákèw̌̀̀

'to fold'

Speaker A $\underline{\text { Speaker B }}$ 


\begin{tabular}{|c|c|c|c|}
\hline$k \partial ́$ w̆̀̀ & ‘to roll’ (Kamanda 1998) & & \\
\hline 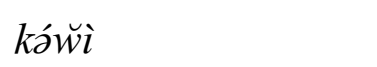 & 'to throw' & $\underline{\text { Speaker A }}$ & $\underline{\text { Speaker B }}$ \\
\hline kándzìngìw̆i & 'to be leafy’ (Kamanda 1998) & & \\
\hline kándìw̆̀̀rì & 'to swarm’ & & \\
\hline káPìwù̀ àngírí & ‘to tumble’ (Kamanda 1998) & & \\
\hline 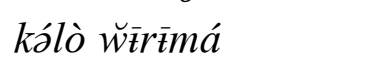 & 'to gnaw around' & & \\
\hline kázù w̌wèrà-w̌wèrà & 'to be loose' & & \\
\hline 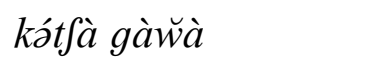 & 'to spill' (Kamanda 1998) & & \\
\hline \multicolumn{4}{|l|}{ Adverbs/Ideophones } \\
\hline tàkàwùàrà & 'crooked' & & \\
\hline “̌ége & 'hot' & $\underline{\text { Speaker A }}$ & $\underline{\text { Speaker B }}$ \\
\hline kèw̌̀̀tò & 'weakness' & & \\
\hline$\breve{w} \grave{i} \imath \grave{i}$ & 'throw out' & Speaker A & $\underline{\text { Speaker B }}$ \\
\hline píngítứt & ‘suddenly’ & & \\
\hline tìndìw̌́trt́ $\sim$ kìngìwérít & 'round' & & \\
\hline
\end{tabular}

5.1.7 Banda, Togbo-Vara [TOR, b7] (D. R. Congo, Central African Republic)

Cotel (1907:x) (Togbo dialect), Tisserant (1931) (Togbo and Vora dialects), Olson (1996) (Togbo dialect), Moñino (1988) (Vara dialect). Cotel and Olson attest it in the words $\breve{v} a$ 'send' and $\breve{v} i$ 'throw'.

5.1.8 Banda, West Central [BBP, b8] (Central African Republic, Sudan). labiodental

Tisserant (1931) (Dakpwa dialect), Santandrea (1965:28) (Golo dialect), Cloarec-Heiss (1978) (Gbi dialect), Moñino (1988) (Dakpa and Wojo dialects). Santandrea attests it in the word v̆a ngu 'swim'. Moñino attests it in the words $\breve{v} a \sim \breve{v} o$ 'send', $k \bar{e} \breve{v} a$ ' 'war', $\breve{v} i$ 'throw', and $n g \bar{v} \breve{v} \bar{l}$ 'navel'.

5.1.9 Ngbundu [NUU, b9] (D. R. Congo). labiodental

Cloarec-Heiss (1978). No data are given.

5.1.10 Mbandja [ZMZ, b10] (D. R. Congo, Central African Republic, Republic of Congo)

Tisserant (1931), Tingbo (1978) (Balawo dialect), Cloarec-Heiss (1978), Moñino (1988), Jim Fultz and Paul Noren (p.c.). Tingbo notes that the articulation is bilabial rather than labiodental. He provides some evidence of contrast. The sound occurs in all major grammatical categories; it is common, occurring in over 30 lexical items; and it can appear in both word-initial and wordmedial positions. Noren attests the sound in the following lexical items: àw̌íngáw̌íngbí 'type of 


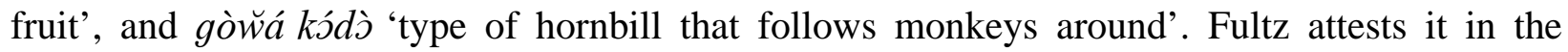
following lexical items:

\begin{tabular}{|c|c|}
\hline Nouns & \\
\hline$\breve{w a y g a ~ j o ~}$ & 'cross' \\
\hline$\breve{w e l a}$ & 'fishing basket' \\
\hline 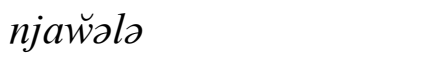 & 'young woman' \\
\hline daw̌wala $\eta g u$ & 'lake’ \\
\hline ă̌wigga & 'rainbow' \\
\hline$a \breve{w} \jmath$ & 'monster' \\
\hline$\breve{w} u l u g u$ & ‘island' \\
\hline Animal and Plant Names & \\
\hline$\breve{w a t s l o ~}$ & 'bee' \\
\hline nekaw̌wala & 'grasshopper' \\
\hline$k a \breve{w} a$ & 'type of tree' \\
\hline$m b \partial \breve{w} \partial$ & ‘tse-tse fly’ \\
\hline$k \supset \breve{w} \partial$ & 'tortoise' \\
\hline Body parts & \\
\hline 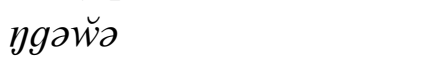 & 'joint' \\
\hline ygaw̌wala & ‘ankle’ \\
\hline 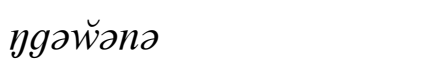 & 'wrist' \\
\hline Verbs & \\
\hline$\breve{w} a$ & 'send' \\
\hline$\breve{w} a$ & 'knock down' \\
\hline$\breve{w}$ alo & 'be supple’ \\
\hline$\breve{w a t a}$ & 'uproot' \\
\hline$g a \breve{w} a$ & ‘jam’ \\
\hline$k a \breve{w} a$ & 'break' \\
\hline$\breve{w \partial}$ & ‘spray’ \\
\hline 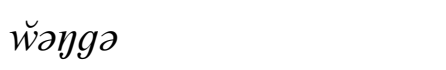 & 'shake' \\
\hline$\breve{w} i$ & 'throw' \\
\hline$\breve{w i l i}$ & 'discuss' \\
\hline$\breve{w} u l u$ & ‘agitate’ \\
\hline$\breve{w u y g u l u ~}$ & 'lament' \\
\hline$\breve{w} u l u$ & 'roll' \\
\hline$\ddot{H} \breve{w} \boldsymbol{H}$ & 'lift' \\
\hline
\end{tabular}


Adjectives

$\breve{w a y g a}$

'alternate’

Adverbs

$\breve{w i l i g i}$

'firmly'

Ideophones

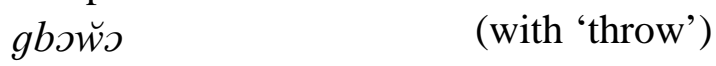

\subsection{Ngbandi}

The labial flap is attested in one Ngbandi language.

5.2.1 Kpatili [KYM, n1] (Central African Republic)

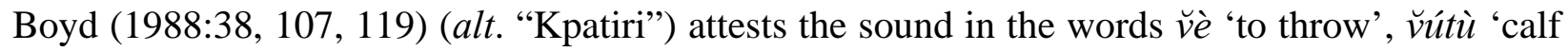
(anat.)', and $k \bar{a} \breve{v} \bar{a}$ 'right'. Grimes (2000) considers Kpatili to be part of the Zande sub-group of Ubangi, but Boyd considers it to be closely related to Ngbandi.

\subsection{Gbaya-Manza-Ngbaka}

The labial flap is attested in four Gbaya-Manza-Ngbaka languages. Grand'Eury (1991) provides evidence for contrast in Ngbaka-Minagende, but she does not consider the sound to be phonemic since it occurs predominantly in ideophones. In the four languages of this language group, the sound occurs in ideophones and animal names. It is considered rare.

5.3.1 Gbaya-Bossangoa [GBP, g1] (Central African Republic). labiodental

Samarin (1966:26), Moñino (1995:162-3). Samarin reports the sound in the following words:

gáva 'fish-trapping ramp' (used only at the town of Bowe)

$\breve{v}$ ' 'descriptive of hitting something'

həv้ 'descriptive of passing on or falling out of sight'

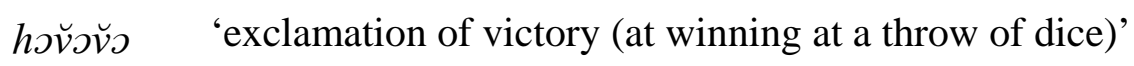

guv̌úu 'a very deep place in a river'

5.3.2 Gbaya, Northwest [GYA, g2] (Central African Republic, Cameroon, Republic of Congo, Nigeria). labiodental

Moñino and Roulon (1972:65) (Gbaya Kara 'Bodoe dialect), Noss (1981:9) (Yaayuwee dialect), Moñino (1995:58). Noss considers the sound a phoneme, but does not provide evidence of contrast. He attests the sound in two ideophones: hív̌ik 'abrupt movement', and $\breve{v} a a$ 'sound

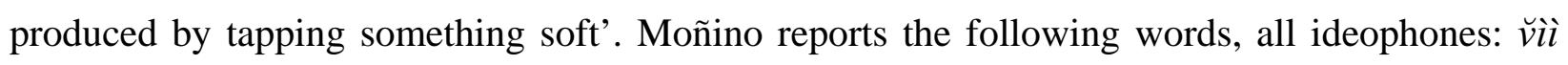




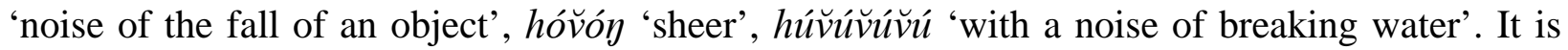
rare.

5.3.3 Manza [MZV, g3] (Central African Republic). labiodental

Moñino (1995:216) (“Manza de Mala”), Cloarec-Heiss (1998) (“Manja”). Moñino attests the sound in the lexical items kùv̆ù 'snail', gùùù-hié-híe 'bird (sp.)' and bóngóv̌̀̀ngò 'agama lizard'. It occurs in intervocalic position. It is rare.

\subsubsection{Ngbaka [NGA, g4] (D. R. Congo, Central African Republic, Republic of Congo)}

Grand'Eury (1991:99); Henrix (2000); Margaret Hill, Elaine Thomas, Timothy Assama Mambo, and Paul Noren (p.c.) (alt. “Ngbaka-Minagende”). Grand'Eury considers the sound labiodental, but Mambo considers it bilabial. Grand'Eury provides evidence of contrast but claims that the sound is only found in ideophones. In contrast, Henrix does list nouns and verbs which contain the sound. Data are from Henrix except where noted.

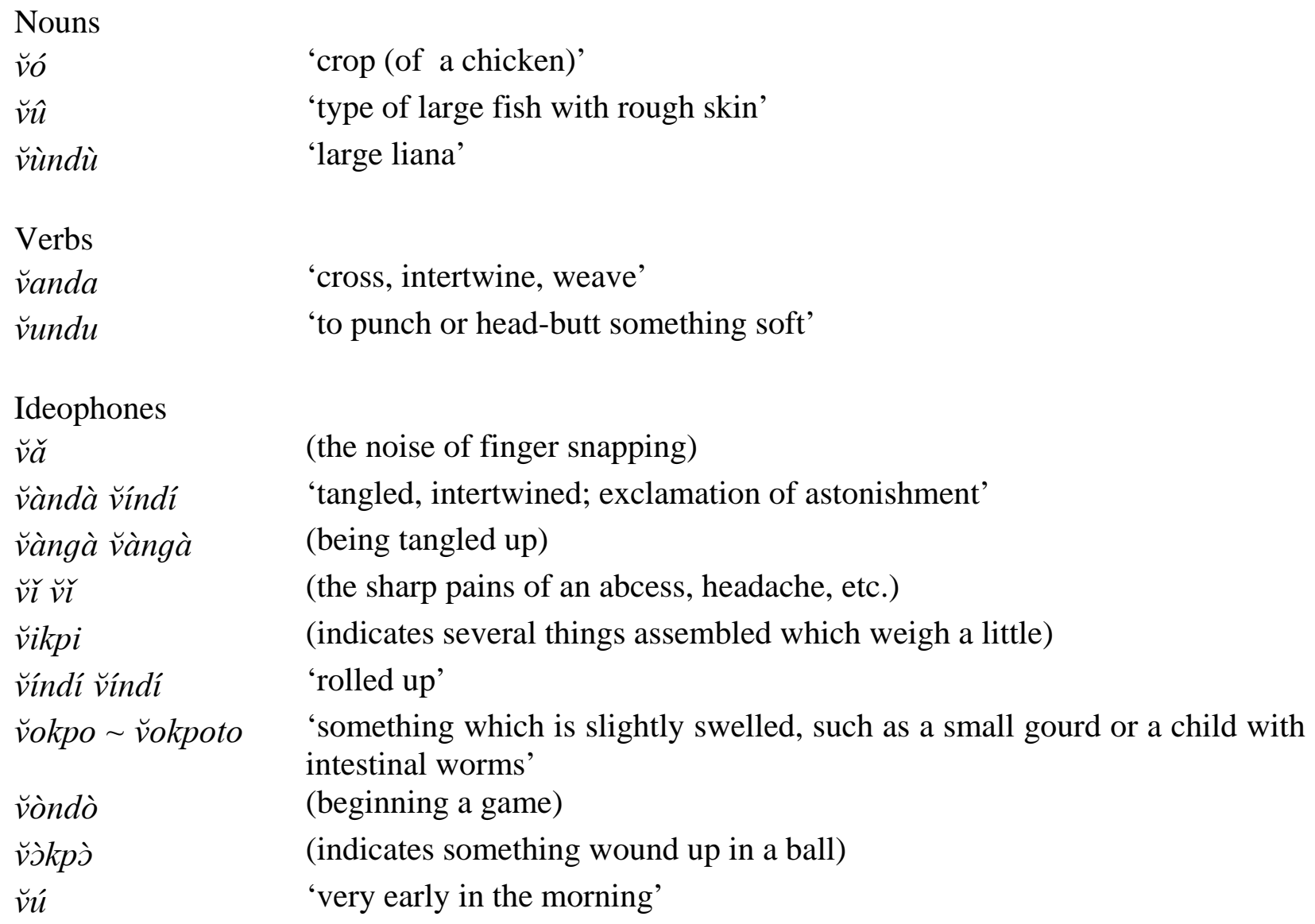

Grand'Eury reports the sound in the words $\breve{v} \grave{u} d \bar{u}$ 'type of fruit', kùv̆ú 'swallow like a pig',

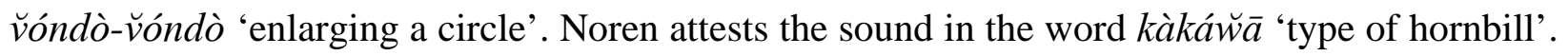
Mambo attests the sound in the ideophone $\breve{w}$ ' 'sound of an animal disappearing into the forest'. 


\subsection{Sere-Ngbaka-Mba}

The labial flap is found in at least seven Sere-Ngbaka-Mba languages. Sources provide evidence for contrast in Ndogo, and further research will likely show contrast in most if not all of the rest of the seven languages. It occurs in both nouns and verbs in all of the languages, in adjectives as well in Sere and Tagbu, and in all grammatical categories in Ndogo. It is attested in over 40 lexical items in Ndogo, in eight lexical items in Sere, and in four or five lexical items in Bai, Feroge, Mangayat, and Tagbu. It occurs in both word-initial and word-medial position in Ndogo.

5.4.1 Bai [BDJ, s1] (Sudan). labiodental

Santandrea (1961:13, 148ff), Tucker and Bryan (1966:92). Santandrea reports it in five words, including both nouns and verbs:

$\begin{array}{ll}\breve{v} a(t a) & \text { 'fall (down)' } \\ \text { bele } \breve{v e r e} & \text { 'lie' } \\ \breve{v} i & \text { 'child' } \\ \breve{v} i-l i & \text { 'girl' } \\ \breve{v} u & \text { 'grinding stone' }\end{array}$

\subsubsection{Feroge [FER, s2] (Sudan)}

Santandrea (1950:21-30, 43-46):

Nouns

kë $\breve{v} \ddot{a} \quad$ 'water'6

de ̌̌ıi 'arrow'

Verbs

vara 'to plaster'

$\breve{v} \ddot{a} g \ddot{a}(h) \quad$ 'to throw'

\subsubsection{Mangayat [MYJ, s3] (Sudan). labiodental}

Santandrea (1950:21-30, 43-46; 1961:171):

Nouns

gemay-këva 'thirst'

(y)këvä 'water'

\footnotetext{
${ }^{6}$ Santandrea employs an umlaut to mark centralization of a vowel (Santandrea 1961:7).
} 


$\begin{array}{ll}\text { ge } \breve{v e g e} & \text { 'arrow' } \\ \text { Verbs } & \\ \breve{v} \ddot{a} \ddot{a} & \text { 'to plaster' } \\ \breve{v} \ddot{a} g \ddot{a}(h) & \text { 'to throw' }\end{array}$

5.4.4 Ndogo [NDZ, s4] (Sudan). labiodental

Tucker (1940:65), Santandrea (1961:13, 87, 148ff), Tucker and Bryan (1966:90-107), Thelwall (1980:80-81), Pozzati (1987), Constance Kutsch Lojenga (p.c.), Peter Rebigo and Wanda Pace (p.c.). Ndogo has a five vowel system in which the vowels transcribed as $\langle\mathrm{e}\rangle$ and $\left.<_{0}\right\rangle$ are pronounced $[\varepsilon]$ and $[0]$, respectively. Rebigo and Pace provide evidence for contrast with other labial sounds before $a$ (reproduced in Olson and Hajek 2003). They report that contrast between the labial flap and other labial sounds in Ndogo is also attested before the other vowels ( $i, e, u$, and $o$ ). The sound occurs in nouns (including animal names), verbs, and adjectives. Pozzati attests the sound in over 40 words. The sound occurs in the core vocabulary words $\breve{v} \bar{\imath}$ 'child', $\breve{v} \bar{a}$ 'to throw', $\breve{v} \bar{e} \bar{e}$ 'to greet, to ask', and $\breve{v} \imath$ ' must, may (auxiliary verb)'. While the sound normally appears in word-initial position, it can also occur in word-medial position. The data below are from Rebigo and Pace and Kutsch Lojenga.

$\begin{array}{ll}\text { Nouns } & \\ \breve{v} a ́ & \text { 'a sprout' } \\ \breve{v} a ́ l a ́ & \text { 'life' } \\ \breve{v} e & \text { 'greeting, question' } \\ \breve{v} e ́ e & \text { 'raw one' } \\ \breve{v} e ̀ e & \text { 'a lie' } \\ \breve{v} \grave{i} & \text { 'flower' } \\ \breve{v} i \grave{ } & \text { 'child' } \\ \text { dìv̌́ } & \text { 'throwing-stick' } \\ \breve{v} o ́ & \text { 'protruding bone' } \\ \breve{v} o ́ k o ́ & \text { 'beam, rod' } \\ \breve{v} \bar{u} u ̀ & \text { 'grinding stone' }\end{array}$

Animal names

v้òóò

$\breve{v}$ úru

'kind of sparrow which makes its nest in holes along high river banks'

gùùgùvúlùv̀ū

'small bird in nightingale family'

'small animal in duiker family'

Verbs

$\breve{v} \bar{a}$

'to throw'

$\breve{v} \bar{a}$

'to sprout' 


\begin{tabular}{|c|c|}
\hline$v \bar{a}(t \bar{o})$ & 'to fall (down)' \\
\hline$\breve{v} \bar{a} l \bar{a}$ & 'to live, to save' \\
\hline$k \bar{a} \breve{v} \bar{a}$ & 'to scratch' \\
\hline$\breve{v} \bar{e} \bar{e}$ & 'to greet, to ask' \\
\hline प⿳亠丷厂犬 & 'to scatter' \\
\hline dê vérè & 'to say a lie' \\
\hline$\breve{v i}$ & 'must, may (auxiliary verb)' \\
\hline$\breve{v} \bar{i} \bar{l}$ & 'to measure, to weigh' \\
\hline$\breve{v i ̀ ̀ ~}$ & 'to open, to part' \\
\hline & to block the way by putting a piece of woo \\
\hline
\end{tabular}

Adjectives

v̌é 'raw, unripe'

gbè lēe $\bar{e} \quad$ 'paralyzed'

5.4.5 Sere [SWF, s5] (D. R. Congo, Central African Republic). labiodental

Santandrea (1961:13, 148ff); Tucker and Bryan (1966:86-107); Thomas et al. (1976:166). Santandrea notes the following data:

Nouns

$\breve{v}$ endi

'brother'

tév̌é

'mahogany'

$\breve{v} i \sim w i$

'child'

$\breve{v i} i-n i$

'girl'

te ̌ri

'grinding stone'

kov̌o

'nose'

Verbs

kava $\quad$ 'to light'

Adjectives

ngov̌a-ngov̌a 'fast (quick)'

5.4.6 Tagbu [TBM, s6] (D. R. Congo). labiodental

Santandrea (1961:13, 91, 148ff):

$\begin{array}{ll}\breve{v} a & \text { 'ask' } \\ \breve{v} a(t a) & \text { 'throw (down)' } \\ \breve{v} a & \text { 'unripe' }\end{array}$


$\breve{v} a-k i-n g o ́ \quad$ 'beyond the river'

mo- $\breve{i} i-n i \quad$ 'girl'

5.4.7 Bangba [BBE, s7] (D. R. Congo)

Boone (1995:52) reports the sound in the lexical item -kov̌o 'to heal'?

\subsubsection{Dongo [DOO, (s8)] (D. R. Congo)}

Pasch (1986:179-180, 389) reports the phoneme / $v /$ in Dongo and attests it in the word vó-غे 'to cut with a knife'. Unfortunately, she does not describe the sound represented by this symbol, but given the geographical location, it is likely a labial flap.

5.4.9 Ngbaka-Ma’bo [NBM, (s9)] (Central African Republic, D. R. Congo, Republic of Congo)

Richardson (1957:91) reports a "flapped v" in Ngbaka-Ma'bo and attests it in the word for 'nine'. However, Cloarec-Heiss (1998) states that this is erroneous.

\subsection{Zande}

The labial flap is attested in one Zande language.

5.5.1 Nzakara [NZK, z1] (Central African Republic, D.R. Congo)

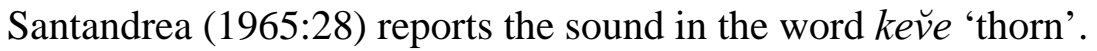

\section{Central Sudanic (West)}

The labial flap is found in seven West Central Sudanic languages. Evidence for contrast is only given for Baka. The sound occurs mostly in nouns, and to a lesser extent in verbs. It is attested in five lexical items in Sar and Yulu, and in fewer lexical items in the remaining languages. Sources consider it to be phonemic in Gbaya and Baka, but the evidence for this is limited.

6.1 Aja [AJA, w1] (Sudan)

Cloarec-Heiss (1998). No data are given.

6.2 Gbaya [KRS, w2] (Sudan). labiodental

Westermann and Ward (1933), Tucker (1940), Tucker and Bryan (1966:63), Brown (1991:54, 63) ("Kreish”). Westermann and Ward consider it rare, but Tucker and Bryan claim that it is

\footnotetext{
${ }^{7}$ Boone (1995) refers to the flap as an "unusual sound”, which he writes as <vh>. We clarified via personal communication that it is indeed a labial flap.
} 


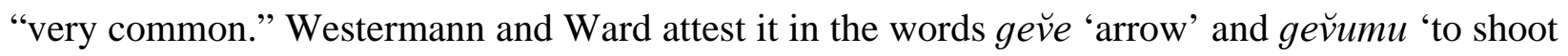
with a bow'. Brown attests it in the word brùtùvúlùvúu nî̀ 'honey badger'. He considers it to be phonemic, but does not provide evidence of contrast.

\subsection{Baka [BDH, w3] (Sudan, D.R. Congo)}

Tucker and Bryan (1966:63, 78), Parker (1985:65-6). Parker gives contrasts with other labial sounds, and he considers it to be a phoneme. He attests it in the word $\breve{v e ̀ n i ́ ~ ' A u g u s t ' . ~ T u c k e r ~ a n d ~}$ Bryan attest it in the word $d \varepsilon \breve{v} \partial$ 'break'. The sound is rare.

6.4 Gula [KCM, w4] (Central African Republic, Sudan)

Santandrea (1970) ("Kara”) and Nougayrol (1999:47) report a labiodental flap in Gula. Nougayrol includes it in his consonant chart, but does not provide contrasts. He reports that the sound is rare. Santandrea attests it in the words v̌ála 'ox' and kiǔi kinvi 'hard sesame'. Nougayrol reports it in the following words (Méré dialect except where noted):

\begin{tabular}{|c|c|}
\hline$\breve{v} a r$ & (imitation of the noise of a slap) \\
\hline$n g \grave{u} \breve{v} a ́$ & 'crowned crane' \\
\hline$n g \bar{a} \breve{v} a ́ r$ & 'run-off ditch' \\
\hline$a \breve{v a r}$ & (imitation of the trotting of a donkey) \\
\hline gav̌ar & $\begin{array}{l}\text { (expressing the sloshing of a liquid transported } \\
\text { in a receptacle) }\end{array}$ \\
\hline$n g \hat{v} \breve{v a ́}$ & ‘crowned crane’ (Zura dialect) \\
\hline àv̆ú & 'It's not true!' \\
\hline
\end{tabular}

6.5 Morokodo [MGC, w5] (Sudan). labiodental

Tucker and Bryan (1966:63). No data are given. It is rare.

6.6 Sar [MWM, w6] (Chad)

Palayer (1970; 1992), Fournier (1977:39). Both authors call it labiodental, but Fournier notes that the lower lip flaps against the upper lip. The sound is rare. Palayer (1970) attests it in the following words:

$\begin{array}{ll}\breve{v} \grave{a} & \text { 'explosion' } \\ \breve{v} \grave{a} y & \text { 'resonance' } \\ \breve{v} a ̀ b & \text { 'tumbling' } \\ \breve{v} a ́ y ̀ & \text { 'banging' } \\ \breve{v} \grave{i ̀} & \text { 'pile' }\end{array}$


6.7 Yulu [YUL, w7] (Sudan, Central African Republic, D.R. Congo). labiodental

Santandrea (1970) (Yulu and Binga dialects) considers the sound to be less common than in Ndogo. The following data are from the Yulu dialect except where noted:

\begin{tabular}{|c|c|}
\hline$k a \breve{v a}$ & 'ashes’ \\
\hline bangoŭai & 'bow’ \\
\hline 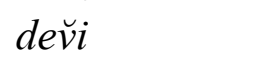 & 'arrow' (Binga dialect) \\
\hline 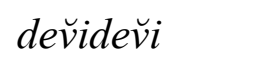 & ‘arrow’ \\
\hline$n g \supset \breve{v o}$ & 'shield' \\
\hline sow-mbov̌o & 'madida' \\
\hline$d u v u \sim n d u \breve{v} u$ & 'waterbuck' \\
\hline
\end{tabular}

\section{Central Sudanic (East)}

The labial flap is found in seven East Central Sudanic Languages. Evidence for contrast is given for Mangbetu. It occurs in nouns, verbs, and numerals in Mangbetu, in nouns and verbs in Lese, and in nouns in Asoa, Lombi, and Mamvu. It is most common in Mangbetu, but appears to be rare in the rest of the languages. It is usually found in word-medial position.

7.1 Asoa [ASV, e1] (D. R. Congo). labiodental

Tucker and Bryan (1966:29) and Demolin (1988:68) report the sound in the word lávúrè 'tail' (Demolin's transcription).

7.2 Lombi [LMI, e2] (D. R. Congo)

Demolin $(1988: 81,83)$ reports the sound in the following lexical items:

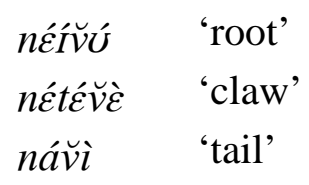

7.3 Mangbetu [MDJ, e3] (D. R. Congo, Uganda)

Tucker and Bryan (1966:29), Larochette (1958) (Mangbetu and Meje dialects), Demolin (1988:69, 81, 83) (Mangbetu and Makere dialects), McKee (1991) (Meje dialect), Demolin (1992)(Mangetu, Medzhe, Malele and Nabulu dialects), Demolin and Teston (1996).

Demolin and Teston (1996:103) state that the articulation of the sound is "a labiodental flap with a bilabial variant". The bilabial variant can occur before $a$ and $o$. The articulation of the sound is the same in "all the languages of the Moru-Mangbetu group...where this sound is encountered (Efe, Lese, Mamvu, and most of the languages of the Mangbetu group)". They provide instrumental evidence to demonstrate that the sound is not an implosive, contra 
Larochette (1958), and not a fricative, contra McKee (1991). In addition, they note that there is a backing movement of the tongue (p. 110).

Demolin (1992) gives evidence for contrast with other labial sounds (reproduced in Olson and Hajek 2003). The sound is well-attested, occurring in over twenty words. It occurs in nouns, verbs, and numerals. Although it is found before all vowels, it only occurs in word-medial position. The following are sample lexical items from Demolin (1992):

Nouns

nă̌i $i \breve{v i}$

néív̆ó èlv̌̀o

'strong wind'

'root'

Animal names

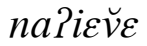

'snail'

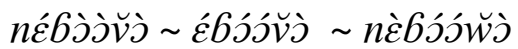

'bumblebee'

$n \varepsilon \breve{v j a} j \breve{v j a}$

'black bird'

Body parts

$n \varepsilon t \varepsilon \breve{v} \varepsilon \sim \dot{\varepsilon} t \grave{\varepsilon} \breve{v} \grave{\varepsilon}$

$n a ̀$ Tjév̆v́

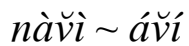

nérjáv̆ì

nébwávìiè

nèmèláv̆í

'nail/claw'

'snail shell'

'tail'

'animal tail'

'monkey tail'

'wildcat tail'

Numerals

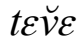

'ten'

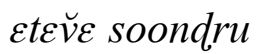

'twenty'

Verbs

nวॅัa

'to play'

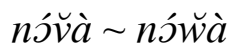

'scatter, disperse'

nóv̌̀

'delight'

nóv̌́

nóv̆ì

'take, capture'

'jump'

nòv้

'fly'

nó $\breve{v} o ̀$

nòv้̀̀ $\sim k \grave{u} \breve{v o ́}$

'scratch, scrape'

$n \grave{a} \breve{v} w a ̀ v \breve{u} \sim k a \grave{v} \grave{u}$

'defecate'

'to blow on fire' 
7.4 Efe [EFE, e4] (D. R. Congo)

Demolin and Teston (1996:103). No data are given.

7.5 Lese [LES, e5] (D. R. Congo). labiodental

Tucker and Bryan (1966:35), Demolin and Teston (1996:103), Constance Kutsch Lojenga (p.c.). In comparing the labial flaps in Ndogo and Lese, Kutsch Lojenga observed that the flap in Lese is "weaker" in that there is no actual contact between the articulators. The following words are from Kutsch Lojenga except where noted.

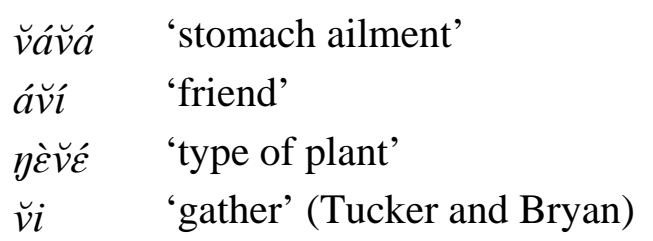

7.6 Mamvu [MDI, e6] (D. R. Congo). labiodental

Tucker and Bryan (1966:29, 46).

$\begin{array}{ll}\grave{a} \breve{v a} & \text { 'father' } \\ \text { umú-èv̌ } & \text { 'my body' }\end{array}$

7.7 Mvuba [MXH, e7] (D. R. Congo, Uganda)

Demolin (1988:68). No data are given.

\section{Austronesian}

The labial flap is attested in one Austronesian language.

8.1 Sika [SKI, m1] (Indonesia). labiodental

Donohue (forthc.) describes the articulation as a voiced labio-dental flap. (He employs a dental diacritic to mark a flapped sound, / $\mathrm{v} /$.) Donohue states that this sound is produced as for a [v] but with labial contact with the inner surface of the upper teeth; this sound is flapped forward from the start to create a sound that is at times affricated ([bv]), and sometimes simply a voiced labiodental stop/flap ([b]). In careful speech, however, [v] is produced.

He provides constrast with [ $\beta]$ and [v]:

$\breve{v o}: t \varepsilon r \quad$ 'I stand a pole in the ground'

Botz:r 'I buy'

vo:ter 'we (INCL.) buy' 
He attests it in four verbs, all in the 1SG form:

$\begin{array}{ll}\breve{v} a l i & \text { 'give' } \\ \breve{v} a i & \text { 'grow' } \\ \breve{v} \text { o'ter } & \text { 'stand a pole in the ground' } \\ \breve{v} \partial \breve{v} a & \text { 'hunt' }\end{array}$

A non-phonemic process of consonant gemination results in [' $\breve{v} ə \breve{v}: a]$ as the phonetic form for this last item.

\section{Other}

There are other possible references to the labial flap in the linguistics literature, but more research is necessary to determine if the sound is in fact found in these languages.

Greenberg (1983) cites Tucker and Bryan (1966) as attesting a labial flap in Mundu [MUH] (Sudan, D. R. Congo), but we could not verify this claim.

Boyd (1974:82-3) lists the Adamawa languages Ngoumi, Touboro, and Pandjama as containing the labial flap. These are all listed as dialects of Karang in Grimes (2000).

Santandrea (1965:28) reports a labiodental flap in the Gäbu dialect of Banda. It is unclear what the classification of this language is. He also mentions its existence in the Ngala dialect of Banda (p. 16). Again, it is unclear what the classification of this language is. The language is moribund.

Cook (1969:39) notes that in Efik, /b/ is pronounced as a "voiced bilabial flap" in ambisyllabic position. He describes the articulation as "made by touching the upper and lower lips together once lightly and releasingly [sic] them rapidly. The lips are touched together only very weakly and are not held closed for any length of time” (p. 39).

No tangengial movement of the lower lip with respect to the upper lip or teeth is mentioned. In addition, Welmers (1973:75) notes that the sound patterns in a similar fashion to alveolar and velar "flaps", which are allophones of /d/ and /g/, respectively. These observations suggest that this sound is likely a tap rather than a flap (Ladefoged and Maddieson 1996:231) and is thus distinct from the labial flap.

Ladefoged (1971:52) reports a "voiced bilabial trill or flap" in Ngwe [NWE] (see also Gregersen 1977:31), but more recent accounts (Maddieson 1989; Njika 1991) clarify that the sound in question is a bilabial trill.

\section{Conclusion}

In this paper, we have presented a large sample of the occurrences of the labial flap in the world's languages, in order to support the generalizations discussed in Olson and Hajek (2003). We have tried to present as complete a sample as possible, given the present status of linguistic field work in Africa and Asia. Detailed samples aid in drawing typologically meaningful generalizations concerning geographically limited linguistic phenomena. 


\section{References}

Barreteau, Daniel. 1988. Description du Mofu-Gudur: langue de la famille tchadique parlée au Cameroun. Paris: Éditions de l’ORSTOM.

Blench, Roger. 1993. An outline classification of the Mambiloid languages. Journal of West African Languages 23/1.105-118.

Bohnhoff, Lee E. 1982. Yag dii (Duru) ideophones. Cahiers du Département des Langues Africaines et Linguistique (Yaoundé) 2.1-14.

Boone, Douglas W. 1995. Bangba survey report. Compendium of survey reports. Vol 2: NonBantu languages. Bunia: SIL.

Boyd, Raymond. 1974. Étude comparative dans le groupe adamawa. (Bibliothèque de la SELAF, 46.) Paris: SELAF.

. 1988. Le kpatiri ou gbāyī, une nouvelle langue du groupe ngbandi. Lexique comparatif des langues oubanguiennes, ed. by Yves Moñino, 35-49. Paris: Geuthner.

- 1994. Historical perspectives on Chamba Daka. (Westafrikanische Studien; Frankfurter Beiträge zur Sprach- und Kulturgeschichte, 6.) Köln: Rüdiger Köppe Verlag.

Brown, D. Richard. 1991. Noteworthy features of Kresh phonology and orthography. Proceedings of the Third Nilo-Saharan Linguistics Colloquium, Kisumu, Kenya, August 4-9, 1986, ed. by Franz Rottland, and Lucia N. Omondi, 53-79. Hamburg: H. Buske.

Cloarec-Heiss, France. 1967. Essai de phonologie du parler banda-linda de Ippy. (Bulletin de la SELAF, 3.) Paris: SELAF.

. 1978. Étude préliminaire à une dialectologie banda. Études comparatives, 11-42. (Bibliothèque de la SELAF, 67.) Paris: SELAF.

- 1986. Dynamique et équilibre d’une syntaxe: le banda-linda de Centrafrique. (Descriptions de langues et monographies ethnolinguistiques, 2). Paris: SELAF/Cambridge: Cambridge University Press.

1998. Entre Oubanguien et Soudan central: les langues banda. Language history and linguistic description in Africa, ed. by Ian Maddieson, and Thomas J. Hinnebusch, 1-16. (Trends in African Linguistics, 2). Trenton, NJ: Africa World Press.

Cook, Thomas L. 1969. The pronunciation of Efik for speakers of English. Bloomington, IN: Indiana University.

Cotel, Pierre. 1907. Dictionnaire français-banda et banda-français précédé d’un essai de grammaire banda. Brazzaville: Mission Catholique.

Demolin, Didier. 1988. Some problems of phonological reconstruction in Central Sudanic. Belgian Journal of Linguistics 3.53-95.

— 1992. Le mangbetu: étude phonétique et phonologique. Bruxelles: Université Libre de Bruxelles dissertation.

Demolin, Didier, and Bernard Teston. 1996. Labiodental flaps in Mangbetu. Journal of the International Phonetic Association 26/2.103-111.

Doke, Clement Martyn. 1931. A comparative study in Shona phonetics. Johannesburg: The University of the Witwatersrand Press.

Donohue, Mark. forthcoming. Sikka notes. Nusa: Linguistic Studies of Indonesian and Other Languages in Indonesia.

Eguchi, Paul Kazuhisa. 1971. Esquisse de la langue mambaï. Kyoto University African Studies 6.139-194.

Elders, Stefan. 2000. Grammaire mundang. Leiden: University of Leiden dissertation. 
Ennulat, Jurgen, and Hélène Ennulat. 1971. Description phonologique Fali (parler de Ram). Yaoundé: Université Fédérale du Cameroun.

Fløttum, Sverre. 1974. Dictionnaire mbum-français. Oslo, ms.

Fortune, George. 1962. Ideophones in Shona: An inaugural lecture given in the University College of Rhodesia and Nyasaland. London: Oxford University Press.

Fournier, Maurice. 1977. Les consonnes du Sar. Études phonologiques tchadiennes, ed. by JeanPierre Caprile, 37-44. Paris: SELAF.

Grand’Eury, Sylvie. 1991. Le parler ngbākā-mīnāgèndē, langue oubanguienne du Zaïre: unités de base, prédication et énonciation. Nancy: Université de Nancy II dissertation.

Greenberg, Joseph H. 1983. Some areal characteristics of African languages. Current approaches to African linguistics 1, ed. by R. Dihoff, 3-22. Dordrecht: Foris Publications.

Gregersen, Edgar A. 1977. Language in Africa: An introductory survey. New York, Paris, London: Gordon and Breach.

Grimes, Barbara F. (ed.) 1996. Ethnologue: Languages of the world. 13th edition. Dallas: SIL.

- (ed.) 2000. Ethnologue: Languages of the world. 14th edition. Dallas: SIL [http://www.ethnologue.com/].

Hagège, Claude. 1968. Description phonologique du mbum. (Bulletin de la SELAF, 5.) Paris: SELAF.

1970. La langue mbum de Nganha (Cameroun): phonologie - grammaire. (Bulletin de la SELAF, 18-19.) Paris: SELAF.

1981. Le mbum. Les langues dans le monde ancien et moderne. Première partie: les langues de l'Afrique subsaharienne, ed. by Jean Perrot, 187-195. Paris: Éditions du Centre National de la Recherche Scientifique.

Hannan, M. 1974. Standard Shona dictionary. Second edition. Salisbury: Rhodesia Literature Bureau.

Hartell, Rhonda L. (ed.) 1993. Alphabets de langues africaines. Dakar: UNESCO and SIL.

Heine, Bernd. 2003. Is Africa a linguistic area? Paper presented at the Fourth World Congress of African Linguistics, New Brunswick, NJ, June 17-22, 2003.

Henrix, Marcel. 2000. Dictionnaire ngbaka-français. Ghent: RECALL.

Hino, Shun'ya. 1978. The classified vocabulary of the Mbum language in Mbang Mboum. Tokyo: Institute for the Study of Languages and Cultures of Asia and Africa (ILCAA).

Hoffmann, Carl. 1963. A grammar of the Margi language. London: Oxford University Press.

Hofmann, Erica. 1990. A preliminary phonology of Bana. Victoria: University of Victoria thesis.

International Phonetic Association. 1989. Report on the 1989 Kiel convention. Journal of the International Phonetic Association 19.67-80.

Jungraithmayr, Herrmann. 1965. Materialien zur Kenntnis des Chip, Montol, Gerka und Burrum (Südplateau, Nordnigerien). Afrika und Übersee 48.161-182. . 1990. Lexique mokilko. Berlin: Dietrich Reimer.

Jungraithmayr, Hermann, and Abakar Adams. 1992. Lexique migama. Berlin: Reimer.

Kamanda Kola. 1998. Étude descriptive du mono: langue oubanguienne du Congo (ex-Zaïre). Bruxelles: Université Libre de Bruxelles dissertation.

Ladefoged, Peter. 1968. A phonetic study of West African languages. Second edition. London: Cambridge University Press.

1971. Preliminaries to linguistic phonetics. Chicago: University of Chicago Press.

. 1982. A course in phonetics. Second edition. New York: Harcourt, Brace, Jovanovich. 
Ladefoged, Peter, and Ian Maddieson. 1996. The sounds of the world's languages. Cambridge, MA: Blackwell.

Larochette, J. 1958. Grammaire des dialectes mangbetu et medje, suivie d'un manuel de conversation et d'un lexique. (Sciences de L’homme, 18.) Tervuren: Annales du Musée Royal du Congo Belge.

Lienhard, Ruth, and Martha Giger. 1975. Daba (parler de Pologozom): Description phonologique. Yaoundé: SIL, ms.

Lim, François. 1997. Description linguistique du kare (phonologie-syntaxe). Paris: Université de la Sorbonne Nouvelle, Paris III dissertation.

Maddieson, Ian. 1989. Aerodynamic constraints on sound change: The case of bilabial trills. UCLA Working Papers in Phonetics 72.91-115.

McKee, Robert G. 1991. The interpretation of consonants with semi-vowel release in Meje (Zaire) stems. Proceedings of the Third Nilo-Saharan Linguistics Colloquium, Kisumu, Kenya, August 4-9, 1986, ed. by Franz Rottland, and Lucia N. Omondi, 181-195. Hamburg: H. Buske.

Mohrlang, Roger. 1972. Higi phonology. (Studies in Nigerian Languages, 2.) Zaria: Institute of Linguistics/ Kano: Centre for the Study of Nigerian Languages, Abdullahi Bayero College, Ahmadu Bello University.

Moñino, Yves. 1995. Le Proto-Gbaya. Essai de linguistique comparative sur vingt-et-une langues d'Afrique centrale. (Langues et Cultures Africaines, 20.) Paris: Peeters. . (ed.) 1988. Lexique comparatif des langues oubanguiennes. Paris: Geuthner.

Moñino, Yves, and Paulette Roulon. 1972. Phonologie du Gbaya Kara 'Bodoe de Ndongue Bongowen (Région de Bouar, République Centrafricaine). (Bibliothèque de la SELAF, 31.) Paris: SELAF.

Moseley, Christopher, and R.E. Asher. 1994. Atlas of the world's languages. London, New York: Routledge.

Njika née Atemajong Justina. 1991. A phonology of Nweh and a proposed orthography. Yaoundé: Université de Yaoundé dissertation for a post-graduate diploma in applied linguistics.

Noss, Philip A. 1981. Gbaya: Phonologie et grammaire. Dialecte yaayuwee. Meiganga: Église Évangélique Luthérienne du Cameroun.

Nougayrol, Pierre. 1999. Les parlers gula: Centrafricaine, Soudan, Tchad. Grammaire et lexique. Paris: CNRS Éditions.

Olson, Kenneth S. 1996. On the comparison and classification of Banda dialects. Chicago Linguistic Society 32/1.267-283.

- 2001. The phonology and morphology of Mono. Chicago: University of Chicago dissertation.

Olson, Kenneth S., and John Hajek. 1999. The phonetic status of the labial flap. Journal of the International Phonetic Association 29/2.100-115.

Olson, Kenneth S., and John Hajek. 2003. Crosslinguistic insights on the labial flap. Linguistic Typology 7/2.157-186.

Olson, Kenneth S., and Brian E. Schrag. 2000. An overview of Mono phonology. Proceedings of the 2nd World Congress of African Linguistics, Leipzig 1997, ed. by H. Ekkehard Wolff, and Orin D. Gensler, 393-409. Köln: Rüdiger Köppe.

Pairault, Claude. 1969. Documents du parler d’Iro. Paris: Klincksieck. 
Palayer, Pierre. 1970. Éléments de grammaire sar (Tchad). (Études Linguistiques, 2.) Lyon: Afrique et langage/Fort-Archambault: College Charles Lwanga. 1992. Dictionnaire sar-français, Tchad. Paris: Geuthner.

Parker, Kirk. 1985. Baka phonology. Occasional Papers in the Study of Sudanese Languages 4.63-85. Juba: Summer Institute of Linguistics, Institute of Regional Languages and University of Juba College of Education.

Pasch, Helma. 1986. Die Mba-Sprachen: Die Nominalklassensysteme und die genetische Gliederung einer Gruppe von Ubangi-Sprachen. Hamburg: Helmut Buske.

Pozzati, Aurelio. 1987. Vocabolario Ndogo - Italiano - Ndogo. Trieste: Universita di Trieste/Roma: Missionari Comboniani.

Richardson, Irvine. 1957. Linguistic survey of the northern Bantu borderland, Vol. 2. London: Oxford University Press (for the International African Institute).

Ruelland, Suzanne. 1988. Dictionnaire tupuri-français-anglais (région de Mindaoré, Tchad). (Langues et cultures africaines 10.) Paris: SELAF.

Samarin, William J. 1966. The Gbeya language: Grammar, texts, and vocabularies. (University of California Publications in Linguistics, 44.) Berkeley: University of California Press.

Sampson, Douglas. 1985. A preliminary phonological overview of Banda-Tangbago. Occasional Papers in the Study of Sudanese Languages 4.133-152. Juba: Summer Institute of Linguistics, Institute of Regional Languages and University of Juba College of Education.

Santandrea, Stefano. 1950. Indri - Togoyo - Ndogo - Feroge - Mangaya - Mondu: Comparative linguistics. Verona: Missioni Africane.

—. 1961. Comparative outline-grammar of Ndogo, Sere, Tagbu, Bai, Bviri. Bologna: Editrice Nigrizia.

1965. Languages of the Banda and Zande groups: A contribution to a comparative study. Naples: Istituto Universitario Orientale.

. 1970. Brief grammar outlines of the Yulu and Kara languages. Bologna: Editrice Nigrizia.

Scott, David Clement. 1929. Dictionary of the Nyanja language: Being the encyclopaedic dictionary of the Mang'anja language. London: United Society for Christian Literature, Lutterworth Press.

Segerer, Guillaume. 1995. Remarques sur la phonologie de la langue duru. Paris: Université de Paris 3, Sorbonne Nouvelle, mémoire de DEA.

Semur, Serge. 1997. Lexique migaama-français. Édition provisoire. Chad: Catholic Church.

Tadadjeu, Maurice, and Etienne Sadembouo (eds.) 1979. Alphabet général des langues camerounaises. (Collection PROPELCA, 1.) Yaoundé: Université de Yaoundé.

Thelwall, Robin. 1980. Trills and flaps. Linguistic studies in honour of Paul Christophersen. Occasional Papers in Linguistics and Language Learning 7.79-84. Coleraine: New University of Ulster.

Thomas, Jacqueline M.-C.; Luc Bouquiaux; and France Cloarec-Heiss. 1976. Initiation à la phonétique: phonétique articulatoire et phonétique distinctive. [Paris]: Presses Universitaires de France.

Tingbo-nyi-Zonga. 1978. Étude grammaticale de la langue mbandza (dialecte de balawo). Lubumbashi: Centre de Linguistique Théorique et Appliquée.

Tisserant, R. P. Charles. 1930. Essai sur la grammaire banda. (Travaux et mémoires de l'Institut d'Ethnologie, 13.) Paris: Institut d'Ethnologie. 
— 1931. Dictionnaire banda-français. (Travaux et mémoires de l’Institut d'Ethnologie, 14.) Paris: Institut d'Ethnologie.

Tucker, A.N. 1940. The Eastern Sudanic languages, Vol 1. London: Oxford University Press (for the International Institute of African Languages and Cultures).

Tucker, A.N., and M.A. Bryan. 1966. Linguistic analyses: The non-Bantu languages of NorthEastern Africa. London, New York, Capetown: Oxford University Press (for the International African Institute).

Ubels, Edward, and Virginia Ubels. 1980. Phonology of Karay. Yaoundé: SIL, ms.

Venberg, Rodney. 1975. Phonetic statement of the Peve language. Africana Marburgensia 8.2643.

Weber, Joan, and Martin Weber. 1987. A phonology of Kwanja (Sundani dialect). Evangelical Lutheran Church of Cameroon, ms.

Welmers, William E. 1973. African language structures. Berkeley: University of California Press.

Westermann, Diedrich, and Ida C. Ward. 1933. Practical phonetics for students of African languages. London: Oxford University Press (for the International African Institute).

Authors' contact information:

Kenneth Olson

SIL

7500 West Camp Wisdom Road

Dallas, TX 75236

USA

http://www.sil.org/ olsonk

Prof. John Hajek

School of languages

University of Melbourne

VIC 3010

Australia

j.hajek@unimelb.edu.au 